Preprint. Article has been published in NEW POLITICAL ECONOMY on 05 Feb 202I: https://doi.org//0.1080//3563467.2021.188/470

\title{
Human Rights and Corporate Reinsurance: From Ensuring Rights to Insuring Risks
}

Christian Scheper' and Johanna Gördemann²

\begin{abstract}
With the aim of grounding the analysis of private transnational human rights governance, the article examines how a European reinsurance company links its human rights policy to its core business of underwriting risks in the case of Belo Monte, a large hydroelectric dam in the Brazilian Amazon. Based on the current international regulatory framework, the global political economy of reinsurance is becoming a constitutive element of human rights governance. Conceptualising underwriting as a social practice, we observe how human rights norms are translated into the corporate form of risks. This process goes beyond questions of norm compliance and involves practices of valuation and boundary-drawing based on the underwriter's competences and background knowledge about reinsurance markets, value chains and corporate hierarchies. We conclude with a critique of private governance as an institutional pillar of the human rights system that rests on business rationales rather than lending institutional power to rights-holders.
\end{abstract}

\section{Introduction}

Transnational private governance has wide-ranging effects on the realisation of human rights. This is particularly obvious in large-scale infrastructure and energy projects, like the 'Belo Monte' dam project on the river Xingu in the Brazilian Amazon. Belo Monte is 'a major cancer in our Xingu, which is consuming and slowly destroying our people. There is nothing worse than killing a people while they are alive; to kill them little by little'. (Juruna as cited by Irigaray 20I4, p. I30). This quote from an activist refers to the massive effects that the dam had on the river, which used to be a basis of life and livelihood for two indigenous peoples who had to be resettled. As often in the context of such mega-projects, judgements and conflicts 'on the ground' collide with transnational private governance commitments by those responsible for the project. The company Munich Re, one of the major insurers of Belo Monte's political and economic constructionrisks, states in their human rights policy: 'We strive to prevent or mitigate any possible adverse human rights impacts that could arise from our business activities. (...) [W] have introduced guide-lines, governance instruments and internal position papers to guide our decision-making in line with conscientious management practices'. (Munich Re 2020). What happens in between such private policy statements and the localised, conflictual ground of human rights governance in practice, often remains cloudy.

This article follows the concept of grounding transnational private governance and traces how a transnational company with holistic human rights commitments incorporates these commitments in

\footnotetext{
${ }^{1}$ Institute for Development and Peace, University of Duisburg-Essen, Duisburg, Germany

${ }^{2}$ Department of Philosophy, University of Duisburg-Essen, Essen, Germany
} 
core business practices. We conduct a single case study and focus on the practice of underwriting construction risks by the reinsurance company Munich Re in the case of the Belo Monte dam. Using documentary analyses and qualitative interviews to trace the company's human rightspolicy, we conceptualise the governance process as translation: international norms are translated to headquarter policies and then to concrete underwriting decisions based on risk assessments.

The result of the social process 'from rights to risks' is a rupture between a strong universalistic policy commitment by the company, and the constrained practices and competing rationales of corporate underwriting. We conclude with a critique: in our case, the regulatory approach to protecting human rights through transnational private governance deviates from the normative idea of rights as lending institutional power to rights-holders. It replaces a rationale of rights with a rationale of risks selected and prioritised by markets and corporate strategy.

Our perspective contributes to the aim of grounding transnational private governance in two ways. First, according to its first dimension (Grounding I; see Graz in this issue), we identify localities of transnational governance: the corporate policy, the practice of underwriting and mediating management tools are understood in their micro-political governing functions. Second, according to its second dimension (Grounding 2; see Graz in this issue), we identify practices of translation from a universalistic discourse of rights to corporate practices of managing risks. Our analysis also contributes to the debate about human rights as social practice. Where corporations develop human rights governance policies, we can assume that they have ambiguous effects for human rights (see Merry 20I5). Finally, from a theoretical perspective, our contribution illustrates the entanglement of micro dynamics and wider structural scales invoked by different varieties of practice theories (see Bueger and Gadinger 2015).

We proceed as follows: Section 2 clarifies our theory and methodology. Section 3 introduces the Belo Monte dam project and contextualises the case study of Munich Re by highlighting two aspects: First, we characterise the political economy of reinsurance. Second, we link our case to the wider debate about transnational private governance by highlighting changes in human rights institutions that assign a new governance role to private corporations. Section 4 examines the translation process from human rights to business risks in Munich Re's governance practices. Section 5 concludes with our critique.

\section{Transnational Private Governance as Translation: Theory and Methodology}

Our approach to the concept of grounding private transnational governance follows the practice turn in international studies (Adler and Pouliot 20l I). This means we trace human rights not as an international-legal norm, but as an object of governance practice. Practices are 'competent performances' (Adler and Pouliot 20II, p. 4). Through patterned activities based on competences and background knowledge, they become socially meaningful. Practice-theoretical work in international studies is mostly characterised by a sociological interest and an anthropological gaze. While it offers a fresh view on rigid ontological dichotomies, such as agent/structure and idea/materiality (see Adler and Pouliot 20 I I), it also creates challenges. One key challenge is the question of scale (Bueger and Gadinger 2015). Different theorists can be located on a continuum between those who emphasise large scales, structural constraints, power relations and reproductive patterns of action, like those who draw on Bourdieu, and those who emphasise fluidity and change, like Latour and ActorNetwork approaches. We suggest a middle ground: we study the form that rights take in concrete social settings in which governance decisions take shape. The form has both material (e.g. a document, instrument, or list) and semiotic dimensions, and it enacts specific rationales of governance.

\section{A Practice-Theoretical Approach to Corporate Human Rights Governance}

Our perspective complements the literature on 'human rights as social practice' (see Merry 2015, Pruce 20I5). We agree with Pruce (20I5, p. 4) that participating in human rights practice means 
'to participate in a structured set of activities and patterned behaviours, governed by rules, relating to a specific professionalised environment'. Yet, our practice perspective does not imply that actors involved are necessarily people 'whose energies are directed at improving the lives of others' and who follow a 'common cause' (Pruce 20I5, p. 4). Human rights practice includes a variety of actors, networks and events, who may or may not follow a common cause, with varying idealsand goals, sometimes converging but often conflicting with internationally codified human rights norms.

In this sense, multinational enterprises have become critical sites of human rights practice. With a changing international normative landscape represented by the United Nations Guiding Principles on Business and Human Rights (UNGPs), business enterprises have become key agents of human rights practice in the last two to three decades (OHCHR 20II, Bernaz 20I7). Even though many large multinationals have developed thorough human rights policies and strategies today, most of them would not call human rights their primary goal and purpose. Therefore, when business enterprises are referenced as actors in human rights practice, it is often with a rather narrow view on compliance. We assume that what is usually referred to as 'norm compliance' involves not just commitment and 'walking the talk', but productive work: corporate practice co-constitutes the object of compliance (Edelman and Talesh 20I I, Merry 20I5). Instead of assuming that human rights exist as social facts qua international law, we suggest that they can mean very different things at the same time - they are performed in practice. I What is done in various localities -from defining codes of conduct to signing a contract - is, in that sense, productive work. It (co-)con- stitutes human rights in practice. Through this perspective, we see rationalities of governance as ways of knowing and being in the world, with local effects on social orders, power, authority and rights. The framework of grounding transnational private governance sheds the light precisely on these effects.

Performances of rights norms in corporate practice are not arbitrary but are based on processes of connecting normative ideas with specific actors, networks, activities, and devices. We call these processes translations. They are central to our understanding of the concept of grounding because they constitute localised processes of change (Waeraas and Nielsen 2016, Graz in this issue) but often remain unnoticed in (macro-)political analyses. The concept of translation has been inscribed in practice-theoretical approaches to the social sciences early on, since these heavily draw on Science and Technology Studies (Callon 1986, Latour 1987). Recently, translation has become a more explicit element in international studies (Berger and Esguerra 2018). Translation can provide the basis for local contestations, but it can also inhibit political debate and contestation, especially where change happens through slick managerial processes, often encoded in governance technologies such as score cards or indicators, hardly noticed by a wider public. While translation entails political, geometric and semiotic dimensions of change (Waeraas and Nielsen 2016), we specifically empha-sise its political aspects. In this respect we stay close to Actor-Network approaches (Waeraas andNielsen 2016), but our analysis of the form of rights also incorporates a strong sense of larger scales of enabling and constraining factors constructed by transnational corporate network relations,as we will further specify in our analysis.

\section{Case Study Methodology}

To study the process of translation we conduct a single case study: Munich Re's governance of human rights in the process of underwriting risks for the Belo Monte dam construction. This allows us to trace localised politics in the process of governance by analysing tools and actors in context. The reason we chose the case of Belo Monte is that it illustrates particularly well typical chal- lenges and disputes related to large-scale hydroelectric dam projects (see Schapper et al. 2019), butalso includes novel transnational governance challenges for enterprises, based on the concept of human rights due diligence, as Section 3 will explain. The reason for our company selection is the 'paradigmatic' character of reinsurance as a site of translation: $(\mathrm{Re})$ insurance is a key capitalist 
practice of valuation under conditions of uncertainty (see Lobo-Guerrero 20II, Graz 2019). Complex, ambiguous and uncertain social phenomena are transferred to calculable risks based on statistics, as Section 3 will show.

Our data consists of industry-, country-, company- and underwriting-specific tools to govern sustainability and human rights issues. Moreover, we conducted three semi-structured interviews in 2016 and 2019 with two persons in the company's Sustainability Department, responsible for what the company calls 'Corporate Responsibility in Business', and with the responsible underwriterin São Paulo in 2016. We also draw on insights from civil society activists, a federal judge in Belémand a public prosecutor engaged with Belo Monte, which we explored through seven semi-struc- tured interviews and two group discussions in Belém and São Paulo in 2015, 2016 and 2017. Our longstretched period of data collection (2015-2019) represents our process-oriented conceptionof governance as translation: Munich Re only developed and refined its human rights policies and tools throughout the last decade, and the dam project - after construction was mostly completedin 2015 and it was partly operational in 2016 - only became fully operational in 2019.

For interpreting our data, we followed human rights norms. They are taken up from international reference documents (UNGPs) by employees in the corporate headquarter (HQ) in Munich and leave 'traces' in tools and procedures down to the underwriting decision in São Paulo. While we assume agency and potentialities for change in employees' everyday practices, we take seriously structural factors mentioned by our interviewees: corporate hierarchy, insurance market and value chain. Rather than understanding these as determining structures, we see them as enabling and constraining factors of private governance 'on the ground'.

\section{Dam Construction and Insurance Business as Sites of Transnational Private Governance}

We will now provide the background and context of our case study. First, we present the Belo Monte project with a focus on its human rights conflicts (3.I); second, we introduce key characteristics of (re)insurance, its political relevance, and introduce the company in focus (3.2); third, we highlight institutional shifts in the human rights system that put private companies in an active governance position (3.3).

\section{The Belo Monte Project}

The Belo Monte hydroelectric dam is situated on the Xingu river in the Brazilian Amazon in the state of Pará. The state of Pará is characterised by a high level of violence and frequent allegations of fundamental land and labour rights violations, mostly related to land grabbing and large-scale infrastructure projects in the Amazon region (Interview Arruda 2015, interview Cunha Fischer and Bernatti 2015). Like many other large-scale dam projects in this region, Belo Monte has a long history that dates back to the 1970s. In the 1980s, the World Bank had already planned to support the original proposals to dam the Xingu river - under the project name 'Kararaô' - but was deterred by massive civil society protests (Interview Xingu Vivo 2015).

Civil society organisations and indigenous groups battled against the dam because it enormously affects indigenous territories and natural habitats (Mc Cormick 2007, 20I0, Bratman 20I5). One of the main concerns is the diversion of the river, which has led to the drying out of a large river bend that serves as a source of drinking water and as a fishing ground for two indigenous peoples (Interview Xingo Vivo 2016; interview Arruda 2016). Further human rights concerns were related to resettlements and a massive population increase in Altamira - the city closest to the construction sites and surrounding villages (Gobbi 2013, interview Arruda 2015). Since the construction of the dam created a high demand for workers, the city was confronted with a massive influx of people seeking employment. This has led to a shortage of basic public services (schools, hospitals, 
sanitation), poor living conditions and a sharp rise in crime rates (Interview Cazetta 20 I5, LAJOUSA Amazônia 2015, Presser 2016).

Despite the protests, the construction of the dam was finally started after the Brazilian government's environmental agency, the Institute of Environment and Renewable Natural Resources (IBAMA), granted partial building licenses in 2010 and $201 \mathrm{I}$. In 2015, when construction was close to completion, both IBAMA and the government agency for indigenous affairs (FUNAI) opposed the granting of the operational license since Norte Energia had not taken the necessary steps to assess and mitigate social and environmental impacts (IBAMA 20I5; Interview Cazetta 20I5). However, IBAMA finally granted the operational license later in the same year. When the main construction phase ended in 2015, about 20,000 workers were laid off, resulting in sharp economic decline and a rise of unemployment in Altamira. A delegation from the UN Working Group on Business and Human Rights visited Brazil and highlighted critical human rights concerns in and around Altamira in 2015. They noted 'significant shortcomings in the way projects to mitigate adverse social impacts were being implemented, resulting in tensions and protests' (OHCHR 20I5, interview Presser 2017). There are detailed documentations of past and ongoing human rights conflicts around the Belo Monte dam, so we will not go further into detail here. ${ }^{2}$ The dam has been partially operational since 2016 and was finalised in 2019.

Belo Monte's project consortium, Norte Energia, obtained most of its funding from a consortium of Brazilian state banks, among them BNDES and Caixa Econômica. Various transnational companies, however, were involved in the design, construction, financing and risk insurance of the project. The total costs are estimated to be close to 29 billion reais (approximately 6.2 billion euros).

\section{'Embracing risk': A Political Economy of Reinsurance}

A large-scale investment like Belo Monte always entails numerous political and economic uncertainties - from unknown construction problems and operational details to political oppositions, protests, riots or strikes, regulatory and other institutional changes, and uncertain environmental influences. All these provide risks for investors and operating companies. The business of insurance is to take over these risks from their customers. Reinsurers then provide services to insurance companies by taking over risks that exceed the latter's capacities. The implementation of major infrastructure projects like Belo Monte thus depends on available reinsurance market capacities. Reinsurers often act as both primary insurers and as reinsurers, making them critical actors in the financial structure of large-scale projects.

From a political economy perspective, (re)insurance represents key features of political authority and is therefore of high interest to the study of transnational private governance. Insurance values and classifies societal phenomena and embraces risks, which then enables others to invest. ${ }^{3}$ This enabling character results from its 'insuring' effect: Once measured in terms of risks, political and economic uncertainties of investment, like mentioned above, are absorbed in the process of balancing statistical probabilities. The law and politics and large numbers combined with the possibility of diversifying risks within one corporation, create the rationale for (re)insurers and explain the central role of the sector for the global economy: it supports extensive capital investments and smoother accumulation processes. Despite the sector's social ordering effects, (re)insurance companies usually come in the guise of highly technical 'background' business-to-business service providers. Scholars of international studies rarely recognise them as relevant global political actors (an exception is Graz 2019).

What makes the business of a reinsurance company particularly interesting from a political perspective is its focus on a variety of risks rather than on a specific field of action within the market. It needs to diversify so it can balance risks. Therefore, it also needs a clear understanding of many heterogeneous contexts and industries. This calls not only for a careful balancing of requirements for liquidity ${ }^{4}$ and granularity (the size of single investments or risks), but also a holistic approach to governing risks. We will, however, see in the following sections how this holistic perspective also 
includes the drawing of boundaries, dividing responsibilities and excluding specific uncertainties from the governance process.

Before we dive into Munich Re's process of governance in the Belo Monte case, we will briefly explain why and how human rights have become a central issue for transnational corporate governance in recent years.

\section{Institutional Shift: Linking Human Rights Norms and Business Practice}

Human rights under international law address the state and inter-state relations. The incorporation of business enterprises and their impacts constitutes a key challenge for the human rights system and its governance. ${ }^{5}$ Throughout the last two decades, the international political path has moved towards a soft law approach. Human rights have become subject to a global governance paradigm that seeks to improve the protection of rights by actively incorporating private companies as responsible agents in the human rights system (Ruggie 2014). ${ }^{6}$ This has pulled the state-focused human rights concept into the powerful undertows of transnational private governance and corporate responsibility discourses.

The most important landmark in this respect are the UNGPs, which were unanimously endorsed by the Human Rights Council in $20 \mathrm{II}$ (OHCHR 20I I). The UNGPs emphasise a corporate responsibility to respect human rights. The concept of responsibility does not legally bind companies but offers normative policy guidance on how to act with due diligence. This involves the need to communicate a policy commitment on human rights, to regularly conduct risk assessments (focused on the risks for rights-holders), and to avoid or mitigate adverse human rights impacts. The UNGPs also seek to encourage companies by stressing businesses' self-interest in respecting human rights and by calling on national governments to flank corporate responsibility efforts, thus creating a mixture of transnational private governance and public regulation. This 'smart mix' approach to regulating human rights has aroused many controversies among scholars and human rights activists. While most discussions focus on legal aspects (see Deva and Bilchitz 20I3), scholars of human rights as social practice have also prompted the argument that corporate practices can turn market rationales and business ethics into de facto bases for drawing boundaries to human rights norms (Merry 2015, Scheper 2015).

The institutional change has in fact led to shifts in corporate governance strategies and a controversial debate about their impacts. Today large multinational enterprises develop strategies on human rights due diligence. We will now turn to Munich Re and their governance process in the Belo Monte case.

\section{Underwriting Belo Monte}

To reconstruct how Munich Re transfers human rights norms to its underwriting process in the Belo Monte case, we start with an introduction to the company, its sustainability policies and its role in the Belo Monte project (4.I). We then examine the process of translation, in which we highlight two different governance rationales: rights and risks (4.2). We then discuss what we call competences and background knowledge as enabling and constraining factors of governance practice (4.3).

\section{Munich Re's Reinsurance Rationale and Private Human Rights Governance}

Munich Re, one of the world's largest reinsurance companies based in Munich, sees itself as a sustainable and responsible company with a 'shared-value approach' (Interview Munich Re HQ 2016). It is a member of the UN Global Compact and has signed the Principles for Sustainable Insurance (PSI) and the Principles for Responsible Investment (PRI). It is also one of the leading companies in shaping these international industry standards for sustainable reinsurance, including the development of sector- and country-specific environmental, social and governance (ESG) criteria, as well as 
their integration in (re)insurance underwriting (Interview Munich Re HQ 20I6). Human rights have recently emerged as an important governance parameter for the company. It aims at a due diligence approach as suggested by the UNGPs. This includes assessing human rights risks and implementing measures for their avoidance or mitigation, comprising its own operations as well as those of their customers and business partners (see OHCHR 20II, Interview Munich Re HQ 2016). ${ }^{7}$ Most of the company's human rights governance instruments have been updated and further developed throughout the last decade, partly based on its involvement in contested projects like Belo Monte.

Munich Re took over about 20 percent of the construction-related risks of Belo Monte as a primary insurer through its Brazilian subsidiary. It also acted as a reinsurer for a couple of other primary insurance companies involved, which added up to an insured amount of 7.6 billion reais (approximately I.6 billion euros). The company came to public attention as one of the 'enablers' of the Belo Monte project shortly after it got involved in the project, which led to its exclusion from the Global Challenges Index, a sustainability index published in Germany (Global Challenges Index 2019). The company recognised that this might lead to reputational loss and related risks for its business strat-

egy. Today, it includes commitments to international and national principles and guidelines, company-specific codes and policies, and specific governance tools (Munich Re 2018). In 20II, during the original process of underwriting Belo Monte, these standards were not yet fully developed and the UNGPs had just been endorsed by the Human Rights Council; however, Munich $\operatorname{Re}$ conducted a 're-underwriting' process a couple of years later, confirming that the underwriting process was still in line with company policies and governance tools (Interview Munich Re HQ 2019).

The core sustainability and human rights governance fora in the company consist of a Group Corporate Responsibility Committee, a Reputational Risk Committee and a Whistleblowing Portal. The governance tools for core business activities, which we will describe in the following, are the company's policy statements, a sector-specific 'heat map' for governing reinsurance sustainability risks, and a specific underwriting tool based on ESG criteria (Interview Munich Re 2016).

\section{The Translation Process: From Rights to Risks}

We structure our findings according to four critical changes we find in the process of translation of rights norms to governance tools: (I) Universalistic rights norms are transformed into corporate principles and guidelines (rights become principles); (2) corporate principles are transposed to the valuation of sector-specific risks (principles become risks); (3) case-specific risks are evaluated based on the underwriter's knowledge and competences (risks become prioritised and selected); (4) once ESG criteria are met, the underwriting process focuses on technical risks of financial loss for the company (risks become thinned out). Afterwards, we will reflect on the difference between the governance rationales of rights and risks.

We can see the first change in the corporate headquarter. Corporate policy formulation takes up the logic of rights and articulates its responsibility as a fundamental principle:

\footnotetext{
Munich Re (Group) is committed to respecting human rights in line with internationally accepted human rights principles and the United Nations Guiding Principles on Business and Human Rights. We strive to prevent or mitigate potential adverse human-rights impacts that could arise from our business activities. To systematically identify these, we have defined four dimensions: employees, procurement, (re)insurance business and asset management. For each of these dimensions, we have implemented a set of policies, governance instruments and internal position papers to guide our decision-making and responsible business conduct.
}

The principle is then taken up by three distinct governance mechanisms. First, for its core business, the company draws boundaries by defining 'no-go areas' (Interview Munich Re HQ 2016). It determines regions, products and sectors where business is considered unacceptable. This represents a form of governance based on the rationale of (legal and moral) principles. In addition to these nogo areas, the company defines 'sensitive issues', like banned weapons and Arctic drilling, where it draws 'red lines' or delegates business decisions to a specialised panel (Munich Re 2018). 
The second change occurs where business areas are considered acceptable in principle. The company here takes up the content of responsibility principles - human rights and a list of sustainability issues - and evaluates risks of violations. A company employee, usually a country expert within Munich Re, or an external expert transfers ethical and legal norm contents, as he/she sees fit, to a region- and business-specific 'heat map'. The creation of this governance object is a critical moment as it involves (a) categorising human rights by listing potential types of violations (e.g. child labour, violation of worker rights), and (b) linking them to generalised business operations clustered by sector (e.g. mining, dam construction). Information for the heat map is purchased from specialised service companies that offer country risk profiles. The result is a coloured matrix that indicates the company's interpretations of 'potential risk' (yellow), 'elevated risk' (orange) and 'high or direct risk' (red) (Principles for Sustainable Insurance 2019, p. 18; Interview Munich Re 2016; 2019).

We find the third moment of change in the transfer from the sector-specific heat map to the casespecific underwriting process. While the heat map gives a general indication for employees, the company uses another, more specific ESG tool for informing the underwriting process. The tool is a simple electronic table that contains ten ESG criteria. ${ }^{8}$ It is the construction and use of this table that links the corporate policy to the underwriter's desk. The underwriter - in our case she is a civil engineer who works for Munich Re Brazil and is based in São Paulo - begins by focusing on a business opportunity. In a large-scale project like Belo Monte, potential business is usually offered by an insurance broker, a company that specialises in linking customers - here the Norte Energia project consortium - to the insurance and reinsurance markets. The broker takes relevant information about the project and finds suitable insurers and reinsurers to cover the risk. The underwriter only receives a package of information about the planned project from the broker. This is the basis for her core business activity, the consideration of the structure and pricing of reinsurance risks - in our case, engineering risks in the construction of Belo Monte. The underwriter thus engages in a technical evaluation process of calculating suitable coverage for engineering risks based on the financial policies and potential profits and losses for the company (Interview Munich Re São Paulo 2016).

Once the project is identified as a profitable business opportunity, the underwriter fills out the ESG tool provided by her colleagues from Munich. Based on her knowledge about corporate partners involved, the project and the quality of government institutions, she fills out the tool according to her 'feeling'. 9 In our case, this feeling was positive because IBAMA had already provided the necessary license for construction. If this license is granted, the underwriter trusts that ESG criteria are met (Interview Munich Re São Paulo 2016). We need to note that this is the case even though hydroelectric dam construction is categorised as 'red' in three of the six human rights categories on the heat map, and 'orange' in a fourth category. To be manageable for the company, however, these sector-specific 'elevated' and 'high or direct risks' are made subject to case- specific personal assessments by the underwriter, guided by the ESG tool and her professional knowledge and competences. 10

Once the ESG hurdle is cleared and the underwriter considers the project to be in line with the risk criteria, a fourth change takes place. The underwriter conducts her practice of evaluat- ing and pricing technical risks. Human rights considerations now become an aspect of the core business. Another boundary is created: from this point onwards, human rights risks are con- sidered only where they constitute a technical risk for the company. In the Belo Monte case,the coverage included a brief 'Strike, Riots and Civil Commotion' (SRCC) clause, which covers financial losses (e.g. interruption of construction, property damage) resulting from this type of event. It refers only to company risks and not to community risks (Interview Munich Re São Paulo 2016).

So far, we have traced, in a narrow sense, the path of translation from human rights norms and principles towards ESG criteria and sector-specific human rights risks to their subsumption under technical risks. What this narrow perspective already demonstrates is that in some cases, human rights concerns may lead to a change of business, especially if the project violates national laws 
(government licensing). Furthermore, concerns about human rights violations may turn into an actual business risk if they fall under technical construction risks covered by the insurance contract. The Belo Monte construction was in fact stopped several times, due to inadequate implementation of labour rights - incidents that are against the business interests of the reinsurer as the bearer of construction risks, including interruptions that fall under the SRCC clause (Interview Munich $\operatorname{Re}$ HQ 2016).

The rationale of governing therefore is eventually business-led, based on risks of financial loss. This constitutes a deviation from human rights as a governance rationale. Both rights and risks are ways of approaching uncertainty. While the concept of a human right focuses on institutionally empowering an individual against the potentiality of undue exertion of power by authorities (traditionally the state), the concept of risk involves the application of probabilities to measure uncertainty regarding future events. A right thus marks a specific normative position and comes with an enforceable claim (unlike a purely moral claim). It is held by a person or group of persons against specific others (Kramer 1998). This means that for every right there is a right-holder. The persons addressed (duty-bearer) are directed to do something about making the object of the right available to the right-holder. The content of the right is what specifies the normative position of both the right-holder and the duty-bearer in relation to the object - what the right is a right to (Cruft 20I5).

While the rationale of a right as a tool of governance is to provide institutional agency for rightsholders to allow for a specific normative position to be backed by a claim against another, the rationale of governing through risk assumes an existing agential power to measure and weigh probabilities of future harm. With respect to the potential harm and the degree of risk, one would tend to think that some actions are too dangerous, especially from a moral or legal rightsbased standpoint (resembling the 'no-go-areas'). Other kinds of actions, even if they include a possibility of serious harm, would be understood as socially acceptable. Such understandings imply an inherent feature of boundary-drawing and include separate value judgements in governing through risks, which might conflict with the structureand logic of existing rights. Risk-based governance as an element of corporate business conduct shifts the rationale away from the rightsholder (as emphasised by the UNGPs) and his/her insti- tutional empowerment as an instrument against misconduct, towards the company's manage- ment of uncertainty to bear costs in the future.

Nevertheless, one might argue that the rationale of governing through rights and risks might result in comparable governance effects, or that the two can be combined to create effective governance solutions. Indeed, this could be the case if the violation of a right directly triggered a business risk of financial loss. A risk-sensitive company would then act with due care to avoid those risks. This idea also resembles the rationale of the UNGPs. It assumes that the violation of rights, as a violation of social norms, eventually corresponds with business risks and, therefore, with companies' own interest, either due to reputational risks (or other inherent market risks) or due to institutional realignments that create legal sanctions or other consequences for business. II However, as our case shows, the shift from rights to risks leaves critical gaps, sothat business risks and the effective governance outcomes do not materialise in line with the concept of rights. Once human rights norms are subject to the risk-based governance at thelevel of underwriting, there are only two possibilities regarding how human rights challenges associated with dam construction may become relevant for governance decisions: they carry weight either at the level of the underwriters' use of the ESG tool - which in our case would only have happened if the project had not received a government license - or as a tech- nical business risk. Otherwise, human rights violations become an acceptable risk.

To link our narrow perspective on the translation process to the wider framework of grounding private transnational governance, the following provides an interpretation of the enabling and constraining factors for localised governance practices. 


\section{Competences and Background Knowledge: Market, Value Chain, Corporate Hierarchy}

Social practices are patterned performances, so they involve specific competences and background knowledge, which in turn give meaning to what are, otherwise, mere actions (Adler and Pouliot $20 \mathrm{II}$ ). As part of our grounding framework, they represent the macro side, the apparently larger structures of transnational private governance, but they are approached with a specific view on their localised representations and enabling functions 'on the ground', in our case their effects for and perceptions by sustainability managers and underwriter. Following their descriptions of the process, we find three contextual references that they know and use to make sense of the underwriting process: the market (local and global), the reinsurance value chain, and corporate hierarchies.

The first context concerns the global and local reinsurance market. In all descriptions by company representatives, it played a critical role. First, it enables the underwriter to be considered by the broker - whose specific role is to 'know the market' - and it determines the influence the company has over the conditions of the project. Interviewees describe a major transformation in this regard in recent years. In Brazil, there used to be two or three large reinsurance companies, creat-ing high leverage for a global player like Munich $\mathrm{Re}$, whereas now some twenty companies competefor large projects (Interview Munich Re São Paulo 2016). This means that the company does not seeany further scope in a situation where the market offers much more coverage than is required, some- times up to 300 percent (Interview Munich Re HQ 2016). The concept of leverage, which is taken asthe main factor for determining the scope of responsibility in the UNGPs (OHCHR 20I I, Principle 19.b), is very limited here. It means that the due diligence process is reduced largely to decisions about 'nogo areas', as we described above, because the company does not consider its market power to offer any leverage over customers' actions - either Munich Re accepts their conditions or exits the specific market.

Besides the aspect of market influence, the underwriter's (and other employees') knowledge about the market also has effects on the interpretation of ESG criteria. While the logic of reinsurance is diversification, the strategic development of human rights principles-based policies tends to increase pressure towards extending 'no-go-areas'. Thus, such excluded areas are closely entangled with market rationales: For instance, whereas gambling and weapons have long been considered sensitive or immoral sectors, hydroelectric dams, coal mines and cement (among others) are considered increasingly problematic by some but not all companies. A company's interpretation of responsibility and diligence here are highly dependent on their assessment of market conditions: A reinsurance company in a national market with hardly any coal mines is quick to define coal mines as 'no-go-area', others in national markets without nuclear energy would rather exclude nuclear power stations. The decision is a question of reputational risk and of staying able to thoroughly diversify business (Interview Munich Re HQ 2019). The ethical principle becomes subject to the political economy of reinsurance markets.

The second context, the reinsurance value chain, was also highlighted several times by interviewees. The company is usually not in direct contact with the project consortium when the reinsurance assignment is being initiated. Instead, business is mediated by an insurance broker, itself often a large company, which knows the local and global insurance markets and finds potential providers for the project. Although in the Belo Monte case Munich Re also acted as a primary insurer, it alsohad other insurers as direct business partners, increasing the value chain complexity. The number of construction firms directly involved in the project, finally, is very high - 'more like a city', in the underwriter's words (Interview Munich Re São Paulo 2016). What she gets to know about the project therefore initially depends on the broker company, which again follows its own for-profit logic and risk-based governance. 12 In the Belo Monte case, the underwriter asserts that no information on human rights was provided by the broker. This is common practice - unless there are apparent conflicts or problems that the broker considers critical at the stage of underwriting(such as a legal requirement that has not been met). While the underwriting decision must be taken within a few days, further information at a later stage is often assessed by the reinsurer 
itself. Munich Re later conducted site visits in Altamira and used other sources of information when underwriting of risks was already signed and sealed.

The underwriter's knowledge of the value chain is therefore a crucial competence in the underwriting process. This includes her judgement about relevant brokers and her trust in the quality of their business. ${ }^{13}$ Furthermore, it includes her knowledge of the main construction firms and potential primary insurance partners. These are all important inputs for the underwriter's 'gut feeling' whether a project will be conducted responsibly. In her everyday business she is not able to reassess all information received by the broker and would only do so in exceptional cases, such as publicly known protests at the site or other sensitive issues. However, events such as these usually occur much later in the project and in most cases the broker remains the main source of information (Interview Munich Re São Paulo 2016).

The underwriter's trust towards intermediary actors in the value chain is also related to her assumptions of functioning government institutions. In a country like Brazil, which has a wideranging constitution and has signed most of the key international human rights treaties, an underwriter will usually assume that licenses and regulations at the building site are trustworthy. Even if cases of non-compliance are reported, it is not feasible for her to have a full picture of all other scenarios that are characterised by gaps in legislation, incoherent jurisdiction and absence of legal clarity, before a contract is signed (Interview Munich Re São Paulo 2016). The underwriter, in this sense, is not able to close institutional misalignments. In these scenarios, civil society engagement might lead to further investigations by the company at a later stage. This also happened in the case of Belo Monte, where Munich Re eventually engaged - outside of its usual business relations - with the project consortium in order to address some of the severe human rights issues relating to regulatory deficits after they had become a matter of public concern and a business problem, due to construction delays, as described above. Based on the reinsurance contract for the whole construction phase, however, it would have been impossible for the company to withdraw from the project (Interview Munich Re HQ 2019).

The third context is the hierarchical structure of the corporation and related divisions of labour. Holistic human rights responsibility formulated at company headquarters is divided into governance tasks and partial responsibilities at the underwriting level. Although we find a clear commitment to human rights at the company headquarter and a range of no-go-areas, the ensuing responsibility needs to be transferred to all levels of the corporation by management, that is, through delegation and division of responsibilities. The underwriter in Brazil needs to mediate between the generalised commitments made by headquarters through the ESG tool mentioned above, and the much more specific situation of the Belo Monte dam. She assesses ESG criteria - but within the technical and time constraints associated with the task of underwriting risks. The holistic responsibility at the corporate level is transformed into fragments of responsibility for construction-related risks. The every- day 'gut feeling' of the underwriter in filling out the ESG tool thus has clear effects on the scope and reach of what is finally included in an assessment.

\section{Conclusion: Grounding Private Transnational Governance of Human Rights}

We have shown how a reinsurance company linked its human rights commitments to its core business of underwriting in the case of Belo Monte - a process that we have conceptualised as translating rights to risks. Our approach emphasises (a) a process of change when human rights are translated from one governance form to the other - from universal rights norms to company principles, from company principles to ethical and legal risks in specific business areas, and finally to technical risks in the specific case; and (b) the relevance of competences and background knowledge in social practices of reinsurance underwriting, which enable and constrain the translation process: market, value chain and corporate hierarchy.

Our approach illustrates how human rights in a reinsurance company's transnational governance practice can become detached from discourses of legality, justiciability and institutional 
entitlements. In the sense of Grounding I (see Graz in this issue), we have shown how corporate headquarter and the underwriter each are enabled to consider human rights aspects in different ways, but how this powerful disposition provided by the company's commitments and principles is also clearly constrained based on the political economy of reinsurance. The business of underwrit- ing risks constitutes a junction between the normative, principles-based rationale of group-wide cor-porate governance strategies, on the one hand, and the localised, practical conditions of everyday business of risk and price calculation, on the other. Information about complex social situations, like the Belo Monte dam, become mediated through the governance form and its technologies of selection and boundary-drawing, which include both value judgements by those in charge in the company and epistemic gaps in the networks that connect individual rights-holders - via thedam construction site and corporate headquarters - to the underwriter's desk. The heat map, which is a key governance tool, can certainly be considered an example of best practice in sector guidance in the area of sustainability and human rights risks. However, it can only provide a sim- plified idea about the actual situation on the ground. The same holds true for the more specific ESG tool in the underwriting process. This is coupled with the competences and background knowl- edge of the underwriter, leading to her specific 'feeling' for or against the ethical acceptability of aproject, which eventually becomes the critical moment in the valuation and boundary-drawing process.

The discourse of rights is still 'visible' at the level of corporate commitments, and we can certainly speak about 'norm compliance' at the different governance levels of policy and ESG criteria we observed at Munich Re. However, in the sense of Grounding 2, our analysis shows that, although the company's employees might act with due diligence, the discourse of rights is replaced by a discourse of business risks in order to manage uncertainty and enable the underwriter to act. In this process, the ideal of institutionalised rights is substituted by the ideal of morally acceptable business areas and activities (e.g. through 'no-go areas', which are also strategically limited by the reinsurance rationale of diversification), and compliance with norms is limited to adherence to national law (government licenses). Furthermore, whereas the ESG assessment allows the company to 'firm up' human rights responsibility (see Merry 2015), rights as normative claims do not find their way into in the underwriting process. Their traces are reduced to narrow technical risks for the company's financial bottom line.

We have only studied a single case and our methodology hardly allows us to extrapolate our findings. However, key aspects in our analysis show micro-politics that shed additional light on more generalised critique against using transnational private governance as an institutional pillarof the human rights system. The company's processes hint at the limits of a delegated responsibilityfor correcting institutional misalignments in the global political economy without further regulatory infrastructure (see Parker and Howe 20I2). Whereas shifts from one governance form to the other can be understood as necessary steps to make business manageable, these translation processes are also political: The politics of transnational governance here is characterised by selective, exclusive and boundary-drawing aspects of social practice in private companies. Even if the company acts 'responsibly' in the sense of a 'sector leader', like Munich Re in our case, the business context that enables and constrains decision-making narrows down the effectiveness of private human rights diligence for individual rights-holders. Contestation and struggle around the Belo Monte project hardly became visible at the time of underwriting, which is conducted in light of corporate governance tools, hierarchy, market and value chain. Our criticism is not against Munich Re or individual employees, but nor would we praise the company's human rights policy. Our analysis did not evaluate the company's individual performance in relation to other companies or its own capacities. Furthermore, our critique does not mean that we consider corporate responsibility to respect human rights a meaningless endeavour - it could lead to organisational change and be combined with institutional reforms to empower rights-holders. Rather, our interest lies in the political effects of governance as translation, i.e. of shifting the rationale of regulating human rights through private governance. It is 
through the grounding framework and our focus on micro-political aspects of change that the ambiguous character of 'firming up' human rights through corporate governance becomes visible. This shift means a transition from a perspective on the institutional power of rights- holders to performative practices of corporations and the calculation of business risks. As a regulat-ory approach, it is incompatible with the rationale of individual rights if not coupled with further regulatory reforms.

\section{Notes}

I. On the performance of corporate practices 'by collectives in unison', see Adler and Pouliot (20II, p. 8); on performative aspects of corporate indicators in the area of human rights, see Merry (2015).

2. See, e.g. OHCHR (2015). For a detailed discussion of human rights concerns related to Belo Monte and indigenous peoples, see, for example, Jaichand and Sampaio (2013).

3. On public/private logics of spreading and embracing risks, see Baker and Simon (2010).

4. Legal requirements for insurers' liquidity are regulated by the Solvency II standard (see Graz 2019).

5. For critical discussions see (Wettstein 2012, Cragg et al. 2012, Deva and Bilchitz 2013, Scheper 2015). For a history of the law and policy of business and human rights see Bernaz (2017).

6. While there is also an international working group on a binding international treaty on human rights and private corporations, the current soft law approach is still dominant. It characterizes various international and private policy guidelines and initiatives.

7. The UNGPs are clear in their emphasis of human rights risks as referring to risks borne by rights holders as opposed to risks for the company (see OHCHR 20II, Principle 17, Commentary).

8. 'Environment: pollution prevention, conservation of natural resources and biodiversity; social: political contest and public awareness, labor and working conditions, health, safety and security for the community, displacement of people, cultural heritage; governance implications: responsible and correct planning and evaluation, compliance, consultation and transparency' (Munich Re 2018, p. 14).

9. Both representatives at company headquarters and the underwriter used this word to describe to us the actual decision relating to a specific evaluation.

10. If the underwriter sees a potentially unacceptable ESG risk, she will withdraw from the project, ask for further information from the broker or formulate contractual conditions that must be met (e.g. granting of a government license).

II. Reputational risks are obvious only for some companies. Other financial and legal consequences depend on the context, see OHCHR (20II, Principle 19). Normatively, however, they could be derived from the State duty to protect and the need for access to effective remedy.

12. While our study focuses solely on the micro process within Munich Re, the broker and insurance value chain also hint at the key role of intermediaries in transnational governance (Abbott et al. 2017).

13. This resembles critical research on Global Value Chains on the power of conventions for normative and cognitive aspects of governance, see Ponte and Gibbon (2005).

\section{Notes on contributors}

Christian Scheper is a Senior Researcher at the Institute for Development and Peace, Faculty of Social Sciences, at the University of Duisburg-Essen. His research is in the field of international politics and global governance, transnational regulation, private enterprises and corporate accountability, human rights and labour standards.

Johanna Gördemann is a Researcher at the Institute of Philosophy, Faculty of Humanities, at the University of DuisburgEssen. Her research is in the field of international political theory and cosmopolitan democracy, international legal theory and philosophy of economics, human rights and philosophy of risk. 


\section{ORCID}

Christian Scheper (iD http://orcid.org/0000-0003-2392-1614

\section{References}

Abbott, K.W., Levi-Faur, D., and Snidal, D., 2017. Theorizing regulatory intermediaries. The Annals of the American Academy of Political and Social Science, 670 (I), 14-35.

Adler, E. and Pouliot, V., 20 I I. International practices. International Theory, 3 (I), I-36.

Arruda, 2015. Personal interview with Paula Arruda, activist academic and lawyer, Institute of Legal Sciences, Universidade Federal do Pará (UFPA), on 09 Sep 2015 in Belém, Brazil.

Arruda, 2016. Personal interview with Paula Arruda on 01 Sep 2016d in Belém.

Baker, T. and Simon, J., 2010. Embracing risk: the changing culture of insurance and responsibility. Chicago: University of Chicago Press.

Berger, S. and Esguerra, A., 20I8. Introduction: the objects of translation. In: T. Berger, and A. Esguerra, eds. World politics in translation: power, relationality and difference in global cooperation. London: Routledge, I-2I.

Bernaz, N., 2017. Business and human rights: history, law and policy - bridging the accountability gap. London, New York: Routledge.

Bratman, E., 20I5. Passive revolution in the green economy: activism and the Belo Monte dam. International Environmental Agreements: Politics, Law and Economics, I5 (I), 6I-77.

Bueger, C. and Gadinger, F., 20I5. The play of international practice. International Studies Quarterly, 59 (3), $449-460$.

Callon, M., 1986. Some elements of a sociology of translation. Domestication of the scallops and fisherman of St. Brieuc Bay. In: J. Law, ed. Power, action and belief: a new sociology of knowledge? London/ New York: Routledge, 196-223.

Cazetta, 20I5. Personal interview with Uribatan Cazetta, Federal Prosecutor, Ministério Público Federal, on 25 Sep 2015 in Belém.

Cragg, W., Arnold, D.G., and Muchlinski, P., 20I2. Human rights and business. Business Ethics Quarterly, 22 (I), I-7.

Cruft, R., 2015. From a good life to human rights. Some complications. In: R. Cruft, S. Liao, and M. Renzo, eds. Philosophical foundations of human rights. New York: Oxford University Press, I0I-116.

Cunha Fischer and Bernatti, 20I5. Personal interview with Luly Rodrigues da Cunha Fischer and José Heder Benatti, activist academics at Institute of Legal Sciences, UFPA, on II Sep 2015 in Belém.

Deva, S. and Bilchitz, D., 2013. Human rights obligations of business: beyond the corporate responsibility to respect? New York: Cambridge University Press.

Edelman, L.B. and Talesh, S., 20II. To comply or not to comply - that isn't the question: how organizations construct the meaning of compliance. In: C. Parker and V. Nielsen, eds. Making business behave: understanding and explaining organisational responses to regulation. Cheltenham: Edward Elgar, 103-122.

Gobbi, F., 2013. Brazil's Belo Monte dam project. Financial impact, indigenous peoples' rights \& the environment. Library of the European Parliament [online]. Available from: https:/www.europarl.europa.eu/RegData/bibliotheque/briefing/ 2013/I30579/LDM_BRI(2013)|30579_REVI_EN.pdf [Accessed 28 Aug 2020].

Global Challenges Index, 2019. Global Challenges Index [online]. Available from: http://gcindex.boersenag.de/de/ [Accessed 21 Aug 2019].

Graz, J.-C., 2019. The power of standards: hybrid authority and the globalisation of services. Cambridge: Cambridge University Press.

IBAMA, 20I5. Parecer do Ibama identifica pendências que impedem a emissão da Licença de Operação para Belo Monte. Available from: http://www.ibama.gov.br/noticias/66-2015/393-parecer-do-ibama-identifica-pendencias-queimpedem-a-emissao-da-licenca-de-operacao-para-belo-monte [Accessed 20 Aug 2020].

Irigaray, M., 20I4. 'Killing a people little by little': Belo Monte, human rights and the myth of clean energy. Tipiti: Journal of the Society for the Anthropology of Lowland South America, 12 (2), $128-133$.

Jaichand, V. and Sampaio, A.A., 20I3. Dam and be damned: the adverse impacts of Belo Monte on indigenous peoples in Brazil. Human Rights Quarterly, 35 (2), 408-447.

Kramer, M., 1998. Rights without trimmings. In: M. Kramer, N. Simmonds, and H. Steiner, eds. A debate over rights. Philosophical enquiries. New York: Oxford University Press, 7-III.

LAJOUSA Amazônia, 2015. Group discussion with activist research group on global justice and human rights of indigen- ous communities in the Amazon region, UFPA, 10 Sep 2015 in Belém.

Latour, B., 1987. Reassembling the social: an introduction to actor-network theory. Oxford: Oxford University Press.

Lobo-Guerrero, L., 20II. Insuring security: Biopolitics, security and risk. Abingdon: Routledge.

McCormick, S., 2007. The governance of hydro-electric dams in Brazil. Journal of Latin American Studies, 39 (2), $227-261$.

McCormick, S., 2010. Damming the Amazon: local movements and transnational struggles over water. Society \& Natural Resources, 24 (I), 34-48.

Merry, S.E., 2015. Firming up soft law: the impact of indicators on transnational human rights legal orders. In: T.C. Halliday and G. Shaffer, eds. Transnational legal orders. New York: Cambridge University Press, 374-399. 
Munich Re., 2018. Corporate Responsibility in Business at Munich Re. Presentation by Global Head of Sustainability, Frankfurt, 9 October 2018 [online]. Available from: https:/www.munichre.com/site/corporate/get/documents_EI81196748I/mr/assetpool.shared/Documents/0_Corporate_Website/5_Investor_Relations/Publications/ Presentations/MunichRe_DB_ESG_Days_FFM_2018-10-09.pdf [Accessed 21 Aug 2019].

Munich Re., 2020. Human rights. Version: March 2020 [online]. Available from: https://www.munichre.com/content/ dam/munichre/contentlounge/websitepieces/documents/Human_Rights_declaration_2020.pdf/_jcr_content/ renditions/original./Human_Rights_declaration_2020.pdf [Accessed 22 Aug 2020].

Munich Re HQ, 2016. Telephone interview with two representatives of the Sustainability Department, responsible for Corporate Responsibility in Business, including one member of the Chief Risk Officer Forum.

Munich Re HQ, 2019. Telephone interview with representative of Sustainability Department, focus on Corporate Responsibility in Business, on 21 Aug 2019.

Munich Re São Paulo, 2016. Telephone interview with underwriter responsible for the Belo Monte project, on 18 Nov 2019.

$\mathrm{OHCHR,} \mathrm{20II.} \mathrm{Guiding} \mathrm{principles} \mathrm{on} \mathrm{business} \mathrm{and} \mathrm{human} \mathrm{rights:} \mathrm{implementing} \mathrm{the} \mathrm{United} \mathrm{Nations} \mathrm{"protect,} \mathrm{respect} \mathrm{and}$ Remedy" framework [online]. Geneva: United Nations. Available from: http://www.ohchr.org/Documents/ Publications/GuidingPrinciplesBusinessHR_EN.pdf [Accessed 21 Jul 2019].

OHCHR, 2015. Statement at the end of visit to Brazil by the United Nations working group on business and human rights. Brasilia [online]. Geneva: United Nations. Available from: http://www.ohchr.org/EN/NewsEvents/Pages/DisplayNews. aspx? NewsID=|689|\&LangID=E [Accessed 21 July 2019].

Parker, C., and Howe, J., 2012. Ruggie's diplomatic project and its missing regulatory infrastructure. In: R. Mareș, ed. The UN guiding principles on business and human rights. Foundations and implementation. Leiden: Extenza Turpin distributor, 273-30I.

Ponte, S. and Gibbon, P., 2005. Quality standards, conventions and the governance of global value chains. Economy and Society, 34 (I), I-3I.

Presser, 2016. Presentation by llan Presser, Federal Judge, in the wake of a group discussion on political and judicial conflicts in the Amazon region, on 31 Aug 2016 in Belém.

Presser, 2017. Personal interview with llan Presser on 26 Oct 2017 in Duisburg, Germany.

Principles for Sustainable Insurance, 2019. Underwriting environmental, social and governance risks in non-life insurance business: working draft for public consultation [online]. Available from: https://www.unepfi.org/psi/wp-content/ uploads/2019/05/Underwriting-environmental-social-and-governance-risks-in-non-life-insurance.pdf [2I Aug 20l9].

Pruce, J.R., 2015. The social practice of human rights. New York: Palgrave Macmillan.

Ruggie, J.G., 2014. Global governance and "new governance theory": lessons from business and human rights. Global Governance: A Review of Multilateralism and International Organizations, 20 (I), 5- 17.

Schapper, A., Scheper, C., and Unrau, C., 2019. The material politics of damming water: an introduction. Sustainable Development [online first]. Available from: https://doi.org/10.1002/sd.1992 [Accessed 10 Dec 2019].

Scheper, C., 2015. 'From naming and shaming to knowing and showing': human rights and the power of corporate practice. The International Journal of Human Rights, 19 (6), 737-756.

Waeraas, A. and Nielsen, J.A., 2016. Translation theory 'translated': three perspectives on translation in organizational research. International Journal of Management Reviews, 18 (3), 236-270.

Wettstein, F., 20I2. CSR and the debate on business and human rights: bridging the great divide. Business Ethics Quarterly, 22 (4), 739-770.

Xingo Vivo, 20I5. Personal interview with representative of collective civil society action network 'Xingo Vivo' on I4 Sep 2015 in Belem.

Xingo Vivo, 2016. Personal interview with representative of 'Xingo Vivo' on 02 Sep 2016 in Belem. 